\title{
Statyba
}

\section{ESTIMATION METHOD AND EXPERIMENTAL INVESTIGATION OF STRESS-STRAIN STATE FOR TENSILE RC INCLUDING ASSESSMENT OF SHRINKAGE AND NON-LINEAR STRAINS}

\author{
E. Dulinskas
}

To cite this article: E. Dulinskas (1995) ESTIMATION METHOD AND EXPERIMENTAL INVESTIGATION OF STRESS-STRAIN STATE FOR TENSILE RC INCLUDING ASSESSMENT OF SHRINKAGE AND NON-LINEAR STRAINS, Statyba, 1:3, 30-57, DOI: 10.1080/13921525.1995.10531518

To link to this article: https://doi.org/10.1080/13921525.1995.10531518

Published online: 26 Jul 2012.

Submit your article to this journal 주

Џ Article views: 43 


\section{МЕТОДИКА ОЦЕНКИ И ЭКСПЕРИМЕНТАЛЬНЫЕ ИССЛЕДОВАНИЯ НАПРЯЖЕННО-ДЕФОРМИРОВАННОГО СОСТОЯНИЯ РАСТЯНУТОГО ЖЕЛЕЗОБЕТОНА С УЧЕТОМ УСАДКИ И НЕУПРУГИХ ДЕФОРМАЦИЙ}

\section{Е.Дулинскас}

\section{1. Введение}

Напряженно-деформированное состояние растянутого железобетона зависит как от условий нагружения и окружающей среды, так и от предистории элемента до приложения нагрузок. Как известно, твердение бетона связано с нарастанием его физико-механическн характеристик. Однако одновременно протекает и усадка бетона. Усадка бетона в железобетонном элементе приводит $\mathbf{k}$ появлению напряженно-деформированного состояния в бетоне и арматуре. Свободному сокращению размеров бетона при протекании усадки препятствует арматура. В этом случае арматура сжимается и в ней появляются сжимающие напряжения. В свою очередь арматура растягивает бетон. Этот процесс сопровождается появлением пластических деформаций ползучести, ростом прочности и изменением физикомеханических характеристик бетона. Поэтому напряженно-деформированное состояние железобетона постоянно меняется. Наиболее интенсивно этот процесс протекает в начальный период твердения, а в дальнейшем замедляется. Как известно, усадка бетона в железобетонном элементе при больюм проценте армирования приводит к появлению трецин. Поэтому учет усадки как в натурных конструкциях, так и в экспериментальных исследованиях является важным. Эти вопросы исследовались в работах $[1,2,3,4,5,6]$. Однако совместное напряженнодеформированное состояние от усадки и растягивающего усилия исследовано недостаточно. В настоящей работе предпринята попытка учета усадки, неупругих деформаций, старения и наследственности на всей стадии работы бетона в армированном элементе с учетом и ниспадающей части диаграммы растяжения бетона. 
2. Напряженно-деформированное состояние железобетонного элемента в процессе твердения и усадки бетона

Рассмотрим подробно процесс напряженно-деформированного состояния для центрально армированного элемента, изложенный в $[7,8]$ с целью его контроля в процессе проведения экспериментов на растягиваемых образцах. Измерение усадки бетонного и армированного образца, а также напряженно-деформированное состояние железобетонного образца при усадке бетона показаны на рис. 1, а, б и рис. 2 .
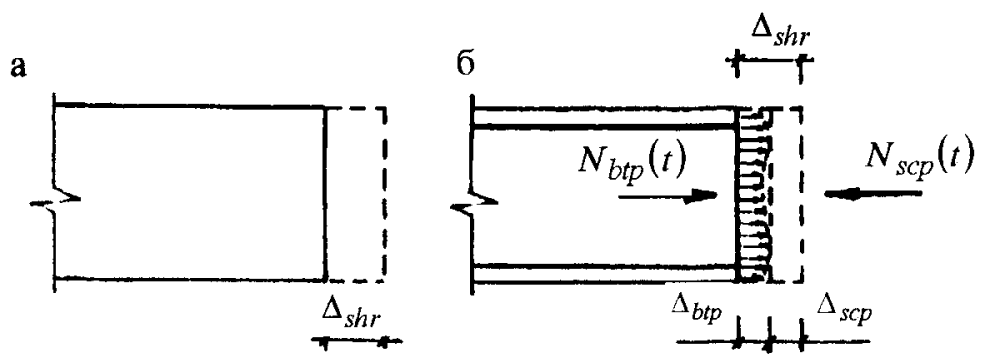

Рис. 1. Деформации усадки образцов: а - бетонного; 6 - железобетонного

В железобетонном образце для любого момента времени $t$ (рис. 1 , б) усилие в бетоне равно усилию в арматуре, а деформации бетона и арматуры при наличии сцепления совместны.
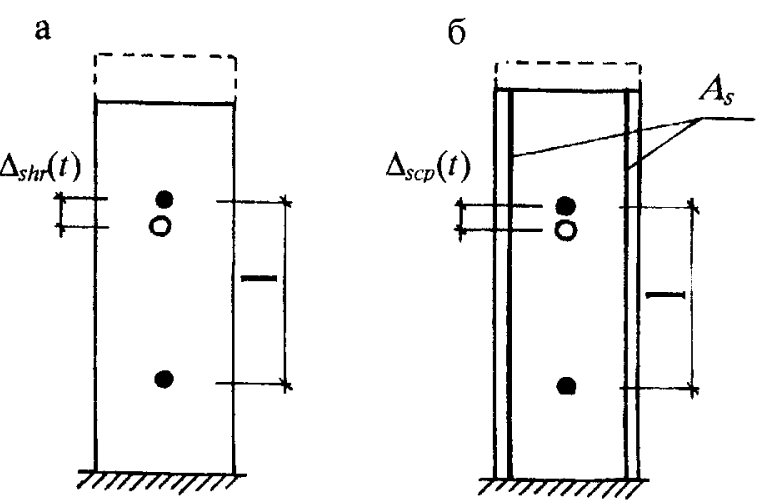

Рис. 2. Измерение усадочных деформаций на опытных образцах:

а - бетонного; 5 - железобетонного 
Напряженно-деформированное состояние описывается двумя уравнениями:

$$
\begin{gathered}
N_{b t p}(t)=N_{s c p}(t) \\
\Delta_{s h r}(t)=\Delta_{b t p}(t)+\Delta_{s c p}(t) ;
\end{gathered}
$$

где $N_{b t p}(t)$ и $N_{s c p}(t)$ - соответственно усилия растяжения бетона и сжатия арматуры в любой момент времени $t$,

$\Delta_{s h r}(t), \Delta_{b t p}(t), \Delta_{s c p}(t) \quad$ - соответственно абсолютные деформации усадки бетонного образца, а также абсолютные деформации растяжения бетона и сжатия арматуры железобетонного образца на одинаковой базе изменения $l$ для обоих образцов в момент времени $t$ (показаны на рис.2, а, б).

На основании абсолютных деформаций усадки образцов получаем относительные деформации усадки бетонного образца

$$
\varepsilon_{s h r}(t)=\Delta_{s h r}(t) / l
$$

и относительные деформации сжатия арматуры или усадку армированного образца

$$
\varepsilon_{s c p}(t)=\varepsilon_{s, s h r}(t)=\Delta_{s c p}(t) / l
$$

Средние растягивающие напряжения в бетоне

$$
\sigma_{b t p}(t)=\varepsilon_{b t p}(t) \cdot E_{b}(t)
$$

и сжимающие напряжения в арматуре

$$
\sigma_{s c p}(t)=\varepsilon_{s c p}(t) \cdot E_{s}(t)
$$

Уравнение равновесия примет вид:

$$
\sigma_{s c p}(t) \cdot A_{s}=\sigma_{b t p}(t) \cdot A_{b}
$$

где $A_{s}$ и $A_{b}$ - соответственно площади арматуры и бетона. Учитывая, что

$$
\begin{aligned}
\mu_{s}=\frac{A_{s}}{A}, a \operatorname{A} A=A_{b}+A_{s}, A_{b}=A \cdot\left(1-\mu_{s}\right), \text { получаем } \\
N_{s c p}(t)=\varepsilon_{s c p}(t) E_{s} \mu_{s} A ;
\end{aligned}
$$




$$
N_{b t p}(t)=\varepsilon_{b t p}(t) E_{b}(t) \cdot A\left(1-\mu_{s}\right)
$$

Из зависимостей (8) и (9) получаем, что

$$
N_{s c p}(t)=\varepsilon_{b c p}(t) \cdot \frac{E_{b}(t)}{E_{s}} \cdot \frac{1-\mu_{s}}{\mu_{s}}
$$

С учетом зависимостей

$$
\alpha_{t}=\frac{E_{s}}{E_{b 0}(t)} \quad \text { и } \quad v_{b t}(t)=\frac{E_{b}(t)}{E_{b 0}(t)}
$$

получаем соотношение

$$
\frac{E_{b}(t)}{E_{s}}=\frac{v_{b t}(t)}{\alpha_{t}}
$$

где $E_{b t}(t)$ и $E_{b 0}(t)$ - средний и начальный (упругий) модули деформаций бетона во время $t$.

После преобразований зависимости (10) получаем напряжения растяжения в бетоне

$$
\sigma_{b t}(t)=\frac{\varepsilon_{s h r} \cdot E_{s} \cdot \frac{v_{b t}(t)}{\alpha_{t}}}{1+\frac{v_{b t}(t)}{\alpha_{t}} \cdot \frac{1-\mu_{s}}{\mu_{s}}}=\varepsilon_{s h r}(t) \cdot \frac{E_{s}}{\frac{\alpha_{t}}{v_{b t}(t)}+\frac{1-\mu_{s}}{\mu_{s}}}
$$

Обозначив

$$
k_{b s}(t)=\frac{1}{\frac{\alpha_{t}}{v_{b t}(t)}+\frac{1-\mu_{s}}{\mu_{s}}},
$$

окончательно получаем

$$
\sigma_{b t p}(t)=\varepsilon_{s h r}(t) \cdot E_{s} \cdot k_{b s}(t)
$$

В [8] приводится зависимость определения напряжений растяжения В упрощенном виде:

$$
\sigma_{b t}(t)=\varepsilon_{s h r} \cdot \frac{1}{\frac{1}{\mu_{s}}+\frac{\alpha_{t}}{v_{b t}(t)}}
$$


В зависимости (15) упрошенно принимается, что $A_{b}=A$.

При проведении экспериментов в момент выдержки образцов до испытаний измеряем $\Delta_{s h r}(t)$ на бетонных образцах и $\Delta_{s, s h r}(t)=\Delta_{s c p}(t)$ на железобетонных образцах. Из экспериментальных испытаний образцов в момент времени $t$ определяем величину модуля упругости бетона $E_{b 0}(t)$ и другие необходимые характеристики. Расчет напряженно-деформированного состояния во время $t$ проводится в следующей последовательности:

По измеренным величинам $\Delta_{s h r}(t)$ и $\Delta_{s c p}(t)$ определяются деформации $\varepsilon_{b p p}(t)$ и $\varepsilon_{s c p}(t)$ по (3) и (4), деформации растянутого бетона $\varepsilon_{b t p}(t)$ по формуле (2). Усилие сжатия в арматуре

$$
N_{s c p}(t)=\varepsilon_{s c p}(t) \cdot A_{s}
$$

и растяжения в бетоне

$$
N_{b t p}(t)=N_{s c p}(t)
$$

Напряжения растяжения бетона

$$
\sigma_{b t p}(t)=\frac{N_{b t p}(t)}{A_{b}}=\frac{N_{b t p}(t)}{A\left(1-\mu_{s}\right)} .
$$

Тогда коэффищиент упругости деформаций бетона на растяжение с учетом суммарных (упругих и неупругих) деформаций бетона определится по зависимости

$$
v_{b t}(t)=\frac{\sigma_{b t p}(t)}{\varepsilon_{b t p}(t) \cdot E_{b 0}(t)}=\frac{\varepsilon_{e l}(t)}{\varepsilon_{b t p}(t)}
$$

Как видно из проведенных теоретических исследований, экспериментальный контроль величин параметров $\varepsilon_{s h r}(t)=\varepsilon_{s h r}, \varepsilon_{s c}(t)$ и $E_{b 0}(t)$ позволяет в любой момент времени определить напряженно-деформированное состояние экспериментальных образцов при усадке бетона в процессе его твердения с учетом наследственности и неуптугих деформаций.

3. Напряженно-деформированное состояние в месте трещинообразования растятиваюих бетонных и железобетонных образцов

Вышепроведенный анализ позволяет обосновать и выбрать методику проведения экспериментов по определению напряженно-деформированного состояния образцов 
к моменту их испытания. В результате проявления усадки бетона, а также роста прочности бетона и протекания ползучести бетона происходит непрерывное изменение напряженно-деформированного состояния в растянутом бетоне и сжатой арматуре. Оценка этого состояния, а также методика контроля изложена ранее Следует отметить, что на начальной стадии приложения кратковременной нагрузки напряжения в сжатой арматуре уменьшаются, а в растянутом бетоне увеличиваются. При этом приложенная внешпяя сила растягивает только бетон, а сжатая арматура упруго восстанавливает свое начальное состояние, уменышая при этом растягивающую бетон силу, обусловленную усадкой бетона. С увеличением внешней растягивающей силы сжимающие напряжения в арматуре достигают нуля. Тогда растягивающее усилие создается только внешней силой и воспринимается одним бетоном. До достижения нулевых напряжений в арматуре суммарное растягивающее усилие в бетоне создавалось как предварительным усилием сжатой арматуры, так и внешней силой. В дальнейшем при увеличении внешнего растягивающего усилия арматура совместно с бетоном работает на растяжение. Следует отметить, что процесс перераспределения растягивающих усилий проходит при наличии неупругих деформаций бетона. Проведем деталыный анализ напряженно-деформированного состояния образца с момента проявления усадки. Следует отметить, что неупругие деформации бетона приводят $\mathrm{K}$ падению сжимающих напряжений в арматуре и уменышению усилия растяжения бетона.

Определение напряженно-деформированного состояния при проявлении усадочных деформаций сводится к введению в упругий расчет фактора времени $t$, старения, а также наследственности. Как известно, теория упругости эти вопросы не рассматривает [9]. Такие задачи решаются в теориях пластичности и ползучести [2, 10]. Однако для инженерных расчетов удобно задачу свести $\mathrm{k}$ упругой начальной сжимающей силе $[3,10]$. Причем решение учитывает все процессы проявления пластических деформаций и наследственности бетона.

Силу, приюженную к железобетонному элементу, можно согласно [3, 10] разделить на два составляющих усилия

$$
F=N_{e l}+N_{p l}
$$

где $N_{e l}$ - часть усилия, когда в бетоне будут нулевые напряжения, а $N_{p l}$ остаточное или предварительное усилие, относящееся только к арматуре.

Причем первую часть усилия $N_{e l}$ можно рассчитывать по упругим характеристикам сечения, а вторая $N_{p l}$ учитывает неупругие свойства бетона. Часть усилия $N_{p l}$ зависит от напряженного состояния, изменения физико-механических 
характеристик, проявления пластических деформаций и может как увеличиваться, так и уменышаться.

Такое разделение усилий было обосновано А.Арупюняном [11]. Позднее С.Александровский в своих исследованиях определил гранищы применения данного принципа, [2], и установил, что он не распространяется на системы с упругоподатливыми связями. Аналогичная методиха применена и при определении напряженно-деформированного состояния сборно-монолитных элементов [3].

В решениях Н.Н.Темного задача в системе с упруго-податливыми связями сводилась к воздействию на систему усилия, зависящего от фактора времени $t$. Принцип разделения усилия в системах без упруго-податливых связей и при наличии таковых применялся нами в исследованиях [10] по огределению напряженно-деформированного состояния изделий при теплообработке, изготовленных стендовым способом и в силовых формах. Эта методика применима и в исследованиях растянутых образцов с учетом воздействия усадки на этапе твердения и выдержки образцов до испытания.

Напряженно-деформированное состояние железобетонного элемента при усадке было рассмотрено и оценено зависимостями (1) - (16). В результате решения приведенных зависимостей с использованием экспериментально контролируемых параметров к моменту испытаний $t$ имеем усилия в арматуре $N_{s c p}(t)$, бетоне $N_{b t p}(t)$, деформации бетона $\varepsilon_{b t p}(t)$ и арматуры $\varepsilon_{s c p}(t)$, а также коэффипиент упругости бетона $v_{b t}(t)$, учитывающий сложное напряженно-деформированное состояние с проявлением неупругих деформаций ползучести бетона. Кроме этого, учитываются и физико-механические характеристики бетона испытанных образцов.

В процессе испытания образцов на растяжение контролируются усилия, деформации бетона и арматуры, поэтому часть усилий и деформаций получаем экспериментально, а другие рассчитываем по теоретическим зависимостям на основе экспериментальных данньх. График зависимости усилий и деформагций, учитывающий начальное напряженно-деформированное состояние, вызванное усадкой в процессе твердения бетона и его изменения в процессе испытания до разруштения образца, показан на рис. 3 .

Начальное напряженно-деформированное состояние показано в системе координат $F_{0} O_{0} \varepsilon_{0}$. Оно характеризуется деформациями свободной усадки бетона $\varepsilon_{s h r}(t)$, деформациями растяжения бетона сжатой арматурой $\varepsilon_{b t p}(t)$, которые разделяются на упругие $\varepsilon_{e l}$ и пластические $\varepsilon_{p l}$, деформациями сжатия арматуры $\varepsilon_{s c p}(t)$, а также усилиями сжатия в арматуре $N_{s c p}(t)$ и растяжения бетона $N_{b t p}(t)$. 


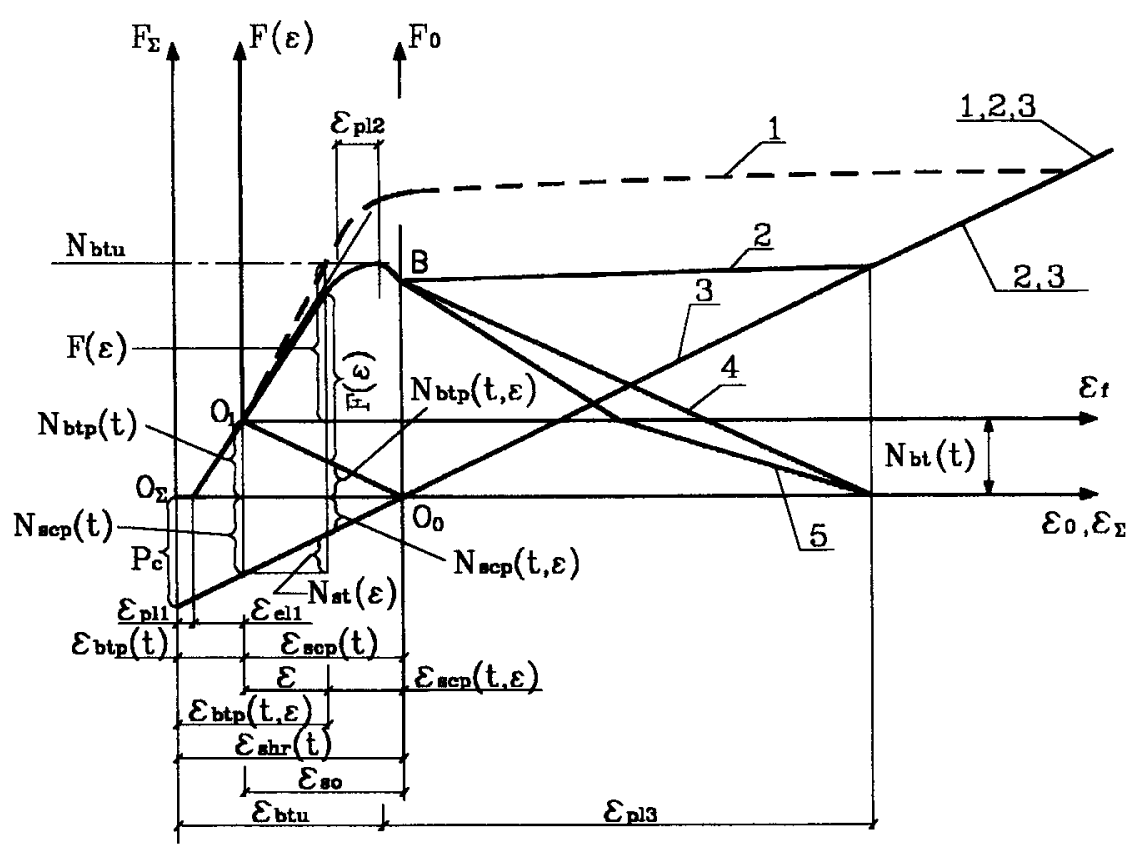

Рис.3. Напряженно-деформированное состояние растягиваемого железобетонного элемента в месте трещинообразования с учетом усадки, неупругих деформаций и ниспадающей части диаграммы $N(t)-\varepsilon: 1$ - кривая суммарного усилия в системе координат $F(\varepsilon) O_{1} \varepsilon_{f} ; 2$ - та же кривая в системе координат $F_{\Sigma} O_{\Sigma} \varepsilon_{\Sigma}$ с учетом уменышения сжимающего усилия; 3 - прямая усилия в арматуре; 4, 5 - ниспадающий участок кривой усилия в бетоне с различным эксцентриситетом приложения силы $F(\varepsilon)$

На этапе твердения бетона и выдержки образцов до испытаний усилия и деформации, обусловленные процессом усадки бетона, роста его прочности и проявлением ползучести бетона, ограничиваются областыо $O_{1}, O_{\Sigma}, P_{c}, O_{0}, O_{1}$. Начальная точка свободных деформаций усадки бетона $\varepsilon_{s h r}(t)$ находится в точке $O_{\Sigma}$, а $\varepsilon_{p l 1}$ - характеризует пластические деформации в бетоне к моменту времени $t$, $\varepsilon_{b t p}(t)$ - полные деформации растяжения бетона в тот же момент времени, $\varepsilon_{s c p}(t)$ характеризует усадочные сжимающие усилия в арматуре. К моменту времени $t$ совместные деформапии железобетонного элемента характеризуются положением точки $O_{1}$, а усилия составляют в бетоне $N_{b t p}(t)$ и арматуре $N_{s c p}(t)$. Предварительное сжимающее усилие в арматуре

$$
P_{c}=A_{s} E_{s} \varepsilon_{s h r}(t)
$$

Входящие в зависимость (18) параметры оговорены ранее. 
Испытания образца начинаются в системе координат $F(\varepsilon) O_{1} \varepsilon_{f}$. Расчетное усилие в бетоне $N_{b t p}(\varepsilon, t)$ определяется в системе координат $F_{\Sigma} O_{\Sigma} \varepsilon_{\Sigma}$.

Приведем основные расчетные условия. При испытании образца от точки $O_{1}$ сжимающее усилие в арматуре постоянно уменышается и в точке $O_{0}$ достигает нуля. Уменышающуюся часть усилия воспринимает растягивающая сила $F(\varepsilon)$, которая растягивает бетон. Усилия в арматуре при испытании

$$
N_{s}(t, \varepsilon)=N_{s c p}(t)-N_{s t}(\varepsilon)
$$

где $N_{s c p}(t)$ - усилие сжатия от усадки ко времени $t, N_{s t}(\varepsilon)$ - снижение усилия из-за упруго-восстановительных деформаций в арматуре при растяжении железобетона (бетона), $\varepsilon$ - относительные деформации армированного образца, вызванные растягивающей силой $F(\varepsilon)$. Уменьшение предварительного растягивающего усилия в aрматуре

$$
N_{s t}(\varepsilon)=\varepsilon E_{s} A_{s}
$$

Если $N_{s c p}(t)>N_{s t}(t)$, усилие в арматуре $N_{s c p}(\varepsilon, t)$ сжимает, а при $N_{s t}(\varepsilon)>N_{s c p}(t)$ усилие $N_{s c p}(\varepsilon, t)$ растягивает.

Полное растягивающее усилие в бетоне

$$
N_{b t}(\varepsilon, t)=N_{b t p}(t)+N_{b t}(\varepsilon)
$$

гле $N_{b t p}(t)$ - растягивающее усилие бетона к моменту времени $t$ от усадки бетона с учетом проявления неупругих деформаций. $N_{b t}(\varepsilon)$ - усилие от растяжения силой $F(\varepsilon)$

Условия равновесия и совместимости деформаций определяются:

$$
\begin{gathered}
\varepsilon_{b t}(\varepsilon)=\varepsilon_{s t}(\varepsilon), \\
N_{b t p}(\varepsilon, t)=F(\varepsilon)+N_{s c p}(\varepsilon, t) ;
\end{gathered}
$$

где $F(\varepsilon)$ - внешняя растягивающая сила. Это показывает, что в этой области кривые $F(\varepsilon)$ и $N_{b t}(\varepsilon)$ совпадают, а координатная система $F(\varepsilon) O_{1} \varepsilon_{f}$ трансформируется по отрезку $O_{1} O_{0}$ к системе $F_{\Sigma} O_{\Sigma} \varepsilon_{\Sigma}$. Кривая (1), показанная в системе $F(\varepsilon) O_{1} \varepsilon_{f}$, не учитывает снижения растяжения бетона при растягивающих деформациях сжатой 
арматуры. Поэтому на участке деформаций $\varepsilon_{s c p}(t)$ кривая (1) более крутая. Кривая (2) может быть построена по (23) в системе координат $F_{\Sigma} O_{\Sigma} \varepsilon_{\Sigma}$. Это показано на рис.3.

На этом этапе испытания до достижения нулевых напряжений в арматуре деформации бетона

$$
\varepsilon_{b t p}(t, \varepsilon)=\varepsilon_{b t p}(t)+\varepsilon
$$

и арматуры

$$
\varepsilon_{s c p}(t, \varepsilon)=\varepsilon_{s c p}(t)-\varepsilon
$$

При достижении нулевых напряжений в арматуре внешняя сила растягивает только бетон:

$$
F(\varepsilon)=N_{b t}(\varepsilon)
$$

a $N_{s}(t, \varepsilon)=0$.

Деформации при $N_{s t}(t, \varepsilon)=0$ составляют:

$$
\varepsilon=\varepsilon_{s c p}(t)=\varepsilon_{s 0}
$$

После перехода усилия в арматуре (кривая 3) на диаграмме через точку $O_{0}$ в ней проявляется растятивающее усилие, вызванное силой $F(\varepsilon)$. На оси деформаций это начинается с точки $O_{0}$. Для координатной системы $F_{\Sigma} O_{\Sigma} \varepsilon_{\Sigma}$ усилия в арматуре

$$
N_{s t}(\varepsilon)=E_{s}\left(\varepsilon-\varepsilon_{s c p}(t)\right) A_{s}
$$

и бетоне

$$
N_{b t}(t, \varepsilon)=N_{s b}(t)+\left(F(\varepsilon)-N_{s t}(\varepsilon)\right)
$$

Привязка деформаций $\varepsilon$ в данном условии производится в координатной системе $F_{\Sigma} O_{\Sigma} \varepsilon_{\Sigma}$ с учетом пластических деформаций $\varepsilon_{p l 1}$.

Следует отметить, что в интервале деформаций, начиная с точки $O_{0}$, арматура растягивается и воспринимает силу растяжения $F(\varepsilon)$ вместе с бетоном. При этом неупругие деформации бетона увеличивают силу растяжения в арматуре $N_{s t}(\varepsilon)$. Общие неупругие деформации бетона в интервале с начала приложения нагрузки до достижения максимальной прочности бетона на растяжение: 


$$
\varepsilon_{p l 2}=\varepsilon_{b t u}-\varepsilon_{b t p}\left(t_{1}\right)
$$

и могут быть легко определены путем выделения из них упругой части для известной доли усилия $F(\varepsilon)$.

Полная диаграмма растяжения бетона (кривая 4) в железобетонном элементе с учетом напряженно-деформированного состояния, вызванного усадкой бетона, изменением его характеристик в процессе твердения, неупругих деформаций, процесса трещинообразования при растяжении, показана в системе координат $F_{\Sigma} O_{\Sigma} \varepsilon_{\Sigma}$. Усилие в арматуре характеризуется прямой 3, её положение характеризуют параметры $P_{c}$ и $\varepsilon_{\text {shr }}(t)$.

Кривая (4) получена по зависимости (29). Точка пересечения кривых (2) и (3) характеризует полное исключение бетона из работы в железобетонном элементе, то есть нормальная трещина полностью пересекла сечение. Предельные деформации растяжения бетона при достижении максимального усилия $N_{b t u}=R_{u}=F_{u}$ составляाют $\varepsilon_{b t u}$. На кривой 4 имеется и нисходяцая часть диаграммы, которая по величине ограничивается точкой пересечения кривой (4) с осью $\varepsilon_{\Sigma}$.

В случае идеального приложения растягивающей силы при нулевом эксцентриситете трещина должна появиться по всему сечению, а кривая (4) не дойдет до оси $\varepsilon_{\Sigma}$. Однако на самом деле появляется эксцентриситет, и сила $F(\varepsilon)$, а также растягивающая $N_{b t}(\varepsilon)$ приложены внецентренно. Физическая нелинейность (анизотропность) свойств бетона по сечению элемента в основном обуславливает эксцентриситет растягивающей силы. Кроме этого, на эксцентриситет влияет и возможное отклонение геометрических размеров, а также расположения арматуры в пределах допусков действуюших стандартов [7]. Поэтому перелом в ниспадающей части диаграммы (кривая 5) характеризует появление нормальной трещины, а дальнейшая пологая её часть определяет и рост ширины нормальной трещины до полного обрыва бетона при внецентренном приложении силы. Отметим, что проявление этой ниспадающей части очень зависит от постоянства скорости деформации $d \varepsilon / d \tau=c o n s t$, где $d \varepsilon$ - приращение деформаций, $d \tau$ - приращение времени. При отклонении от этих условий ниспадающая часть диаграммы может не проявиться (кривая 4).

Если допустить, что бетон не обладает неупругими деформациями, а лишь усадкой, тогда диаграмма деформирования такого материала при испытании (без разрыва) во время $t=t_{1}$ показана на рис.4. Обозначение графиков усилий и деформаций то же, что и на рис.3. Графики на этом рисунке позволяют лучшाе 
понять процесс внутреннего перераспределения усилий на диаграмме при снижении сжимающего усилия в арматуре $\mathrm{c}$ дальнейнгим приложением внешгего растягивающего усилия $F(\varepsilon)$.

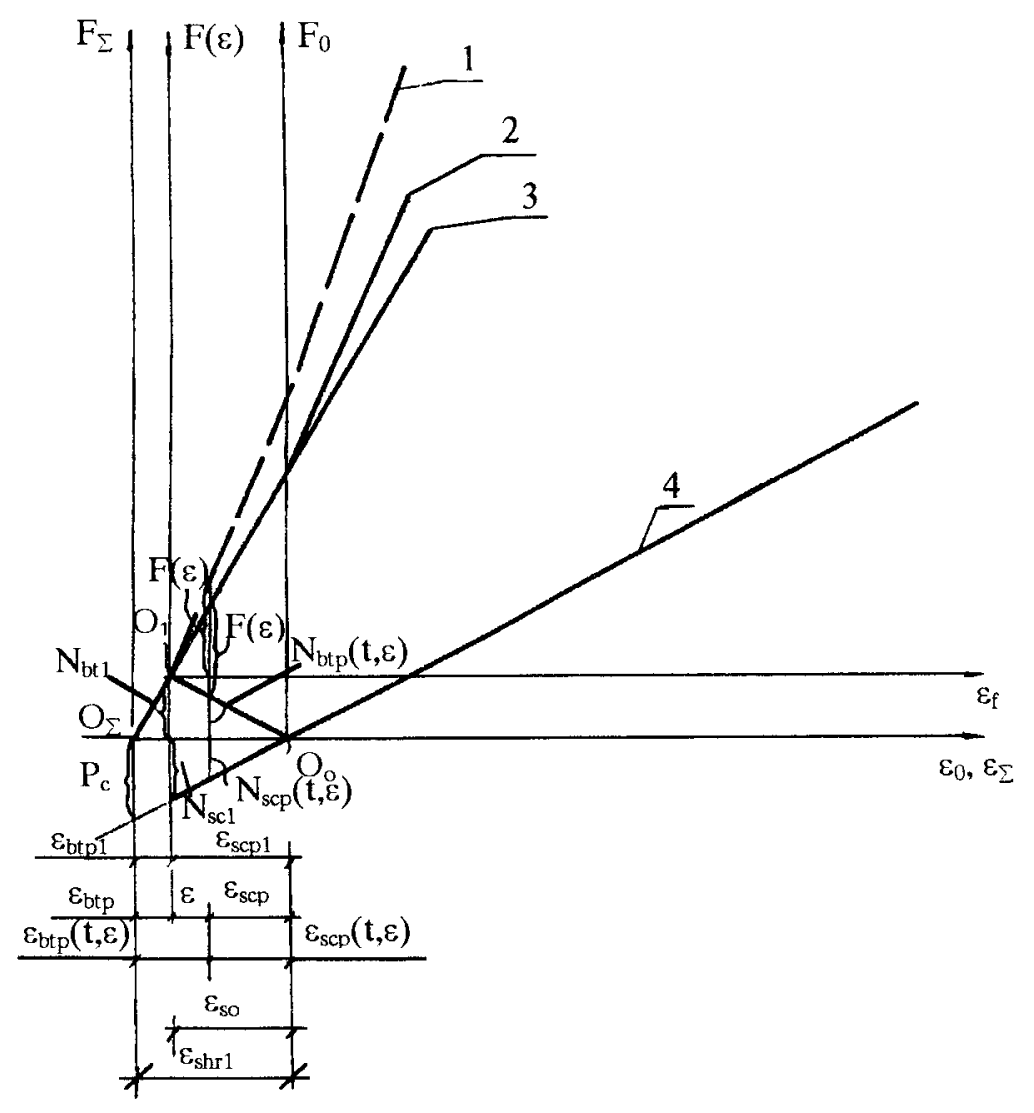

Рис.4. Напряженно-деформированное состояние растягиваемого бетонного образца, не обладающего ползучестью, но с учетом усадочных деформаций: 1 - график растягивающей силы $F(\varepsilon)$ в системе координат $F(\varepsilon) O_{1} \varepsilon_{f} ; 2$ - то же с учетом уменышения растягиваюшепо усилия в арматуре; 3 - график растягивающего усилия в бетоне; 4 - график усилия в необетонированной арматуре

Для описания процесса напряженно-деформированного состояния применяются ранее анализированные зависимости, только с коэффициентом упругости $v_{b t}=1$.

Как уже отмечалось, в бетоне проявляются неупругие деформации как при усадке бетона, так и пгри дальнейшем испытании образца растягивающей силой на растяжение до появления нормальной трещины и обрыва бетона.

Оценку неупругих деформаций бетона можно производить с помоццю коэффициента упругости бетона на любой стадии напряженного состояния, однако 
необходимо иметь четкое разделение упругих и пластических деформаций с учетом их нарастания за весь процесс роста прочности, проявления усадки и растяжения при испытании образца.

Такое разделение деформаций бывает весьма затруднительным и полностью как экспериментальн, тах и теоретически не всегда удается. Остановимся на некоторых особенностях разделения упругих и неупругих деформаций

4. Определение напряженно-деформированного состояния на основе принципов теории ползучести

Согласно нами проведенным исследованиям [10], а также исследованиям других авторов [3] задача определения напряженно-деформированного состояния железобетона упропается благодаря разделению усилия на упругое и пластическое составляющие по зависимости (16).

Решим задачу для процесса усадки бетона к моменту испытания образца $t_{1}$ путем введения коэффициентов, характеризующих композиционную ситему "бетонарматура". Для анализа воспользуемся упрощенной зависимостью определения напряжений в бетоне.

Введем понятие силы предварительного обжатия арматуры при усадке бетона

$$
P_{C}=\varepsilon_{s h r}(t) E_{s} A_{s}
$$

где $\varepsilon_{s h r}(t)=\varepsilon_{s h r}\left(t_{1}\right)=\varepsilon_{s h r 1}$ - деформагци свободной усадки бетона к любому моменту времени $t$ или ко времени испытаний $t=t_{1}$; остальные параметры пояснены ранее Тогда напряжения в бетоне по (15):

$$
\sigma_{b t p}\left(t_{1}\right)=\frac{\varepsilon_{s h r}\left(t_{1}\right) E_{s}}{-\frac{1}{\mu_{s}}+\frac{\alpha_{s}\left(t_{1}\right)}{v_{b t}\left(t_{1}\right)}}=\frac{\sigma_{p c}}{\frac{1}{\mu_{s}}+\frac{\alpha_{s}\left(t_{1}\right)}{v_{b t}\left(t_{1}\right)}}
$$

где $\sigma_{p c}=\varepsilon_{s h r}\left(t_{1}\right) E_{s}$ - напряжения предварительного сжатия арматуры.

По упругому решению с выделением упругой деформации напряжения в бетоне

$$
\sigma_{b t p}\left(t_{1}\right)=\frac{v_{p 1} \varepsilon_{s h r}\left(t_{1}\right) E_{s}}{\frac{1}{\mu_{s}}+\alpha(t)}
$$

где $v_{p 1}=\frac{\varepsilon_{p 1}}{\varepsilon_{s h r}\left(t_{1}\right)}$ 
$\varepsilon_{p 1}$ - угругая часть деформации $\varepsilon_{\text {shr }}\left(t_{1}\right)$.

Приравнивая (30) к (31), после преобразований получаем значение

$$
\varepsilon_{p 1}=\varepsilon_{s h r}\left(t_{1}\right) v_{b t}\left(t_{1}\right) \frac{1+\alpha_{s}\left(t_{1}\right) \mu_{s}}{v_{b t}\left(t_{1}\right)+\alpha_{s}\left(t_{1}\right) \mu_{s}}
$$

Когда неупрутие деформации бетона отсутствуют, $v_{b t}\left(t_{1}\right)=1$, а $\varepsilon_{p 1}=\varepsilon_{s h r}\left(t_{1}\right)=\varepsilon_{s h r 1}$ В этом случае бетон и система "бетон-арматура" деформируются без неупругих деформаций. Коэффициент упругости системы

$$
v_{p}\left(t_{1}\right)=\frac{\varepsilon_{p 1}}{\varepsilon_{s h r}\left(t_{1}\right)}=v_{p 1}=v_{b t}\left(t_{1}\right) \frac{1+\alpha_{s}\left(t_{1}\right) \mu_{s}}{v_{b t}\left(t_{1}\right)+\alpha_{s}\left(t_{1}\right) \mu_{s}}
$$

В зависимости (34) величина $v_{p}\left(t_{1}\right)$ определяется с учетом изменения характеристик бетона $\alpha_{s}\left(t_{1}\right)$, неупругих деформаций $v_{b t}\left(t_{1}\right)$ и процента армирования $\mu_{s}$. Как известно, коэффициент упругости бетона можно выразить так:

$$
v_{p}\left(t_{1}\right)=\frac{\varepsilon_{b t}\left(t_{1}\right)-\varepsilon_{p l}\left(t_{1}\right)}{\varepsilon_{b t}\left(t_{1}\right)}
$$

откуда пластические деформации бетона

$$
\varepsilon_{p l}\left(t_{1}\right)=\varepsilon_{p l 1}=\varepsilon_{b t}\left(t_{1}\right)\left(1-v_{b t}\left(t_{1}\right)\right)
$$

Коэффициент упругости системы (железобетона)

$$
v_{p 1}=\frac{\varepsilon_{s h r}\left(t_{1}\right)-\varepsilon_{p l}\left(t_{1}\right)}{\varepsilon_{s h r}\left(t_{1}\right)}=\frac{\varepsilon_{s h r}-\varepsilon_{p l 1}}{\varepsilon_{s h r}} ;
$$

здесь индекс ' 1 ' означает, что деформации рассматриваются к моменту времени $t=t_{1}$.

Расчеты показывают, что соблюдается равенство

$$
v_{p 1}=\frac{\varepsilon_{s h r}-\varepsilon_{p l 1}}{\varepsilon_{s h r}}=v_{b t}\left(t_{1}\right) \frac{1+\alpha_{s}\left(t_{1}\right) \mu_{s}}{v_{b t}\left(t_{1}\right)+\alpha_{s}\left(t_{1}\right) \mu_{s}}
$$

для принятых значений $v_{b t}(t)=v_{b t}\left(t_{1}\right)$, которое может быть определено и по экспериментальным данным усадки бетона и железобетона. 
После определения неупругих деформаций к моменту времени $t_{1}$ диаграмма $F-\varepsilon$ может быть уточнена. За ее начало можно принять точку, соответствуюцую $\varepsilon_{p /}$ в координатной системе $F_{\Sigma} O_{\Sigma} \varepsilon_{\Sigma}$. При этом следует учесть, что диаграмма растяжения бетона в этой области деформагий получается для стадии разгрузки, то есть без учета неупругих деформаций бетона. Для получения в этой области деформаций диаграммы кривой кратковременного загружения следует выделить из нее деформации ползучести бетона с учетом наследственности к моменту времени $t=t_{1}$.

При растяжении образца силой $F(\varepsilon)$ до достижения нулевых напряжений в сжатой арматуре условие (19) напряжения бетона могут быть определены:

$$
\sigma_{b t}\left(t_{1}, \varepsilon\right)=E_{b 0}\left(t_{1}\right) \varepsilon_{\Sigma} v_{b t}\left(t_{1}, \varepsilon\right)=\frac{N_{s p}\left(t_{1}, \varepsilon\right)+F(\varepsilon)}{A_{b}}
$$

или

где

$$
\sigma_{b t}\left(t_{1}, \varepsilon\right)=\sigma_{b t p}(t, \varepsilon)+\sigma_{b t}(\varepsilon)
$$

$$
\varepsilon_{\Sigma}=\varepsilon_{b t}\left(t_{1}\right)+\varepsilon
$$

при учете полных деформаций и

$$
\varepsilon_{\Sigma}=\varepsilon_{e l 1}+\varepsilon
$$

при учете упругих деформаций (разгрузки).

Из условия (40) коэффициент упругости бетона составляет

$$
v_{b t}\left(t_{1}, \varepsilon\right)=\frac{N_{s p}\left(t_{1}, \varepsilon\right)+F(\varepsilon)}{\varepsilon_{\Sigma} A_{b} E_{b 0}\left(t_{1}\right)}
$$

Для нулевых напряжений в арматуре $N_{s p}\left(t_{1}, \varepsilon\right)=0$, а коэффициент упругости

$$
v_{b t}\left(t_{1}, \varepsilon\right)=\frac{F(\varepsilon)}{\varepsilon_{\Sigma} A_{b} E_{b 0}\left(t_{1}\right)}
$$

где $\varepsilon_{\Sigma}$ определяется по (41) или (42).

Деформация арматуры, когда напряжения в ней $\sigma_{s t}\left(t_{1}, \varepsilon\right)=\sigma_{s c p}\left(t_{1}, \varepsilon\right)=0$, составляет

$$
\varepsilon_{s 0}=\frac{N_{s c p}\left(t_{1}\right)}{A_{s} E_{s}}
$$

С дальнейшим повынением нагрузки сила $F(\varepsilon)$ растягивает бетон и арматуру, тогда нагіряжения в арматуре по (28) составляют 


$$
\sigma_{s t}\left(t_{1}-\varepsilon\right)=E_{s}\left(\varepsilon-\varepsilon_{s 0}\right)
$$

Тогда условие (40) принимает вид:

$$
E_{b 0}\left(t_{1}\right) \varepsilon_{\Sigma} v_{b t}\left(t_{1}, \varepsilon\right)=\frac{F(\varepsilon)-N_{s t}\left(t_{1}, \varepsilon\right)}{\varepsilon_{\Sigma} A_{b} E_{b 0}\left(t_{1}\right)}
$$

где $N_{s t}\left(t_{1}, \varepsilon\right)$ - растягивающее усилие в арматуре после погашения усилия предварительного сжатия, вызванного усадкой бетона. При этом величина деформаций $\varepsilon>\varepsilon_{s 0}$. Из условия (47) при $\varepsilon>\varepsilon_{s 0}$ коэффициент упругости бетона

$$
v_{b t}\left(t_{1}, \varepsilon\right)=\frac{F(\varepsilon)-N_{s t}\left(t_{1}, \varepsilon\right)}{\varepsilon_{\Sigma} A_{b} E_{b 0}\left(t_{1}\right)}
$$

Работа бетона на растяжение в ниспадающей части диаграммы заканчивается, когда $F(\varepsilon)=N_{s t}\left(t_{1}, \varepsilon\right)$, то есть все усилие $F(\varepsilon)$ уже воспринимает растянутая арматура.

Входящие в зависимость (48) параметры оговорены ранее. С увеличением растягивающей силы $F(\varepsilon)$ снижается величина коэффициента упругости $v_{b t}\left(t_{1}, \varepsilon\right)$ и в точке максимума диаграммы $N_{b t u}=N_{b t u}\left(t_{1}, \varepsilon\right)$ достигает величины $v_{b t u}\left(t_{1}, \varepsilon\right)$.

Прочность бетона на растяжение

$$
R_{b t u}=\frac{N_{b t u}\left(t_{1}, \varepsilon\right)}{A_{b}}=E_{b 0}\left(t_{1}\right) \varepsilon_{b t u}\left(t_{1}, \varepsilon\right) v_{b t u}\left(t_{1}, \varepsilon\right)
$$

Если условия испытания обеспечивают постоянную скорость изменения деформаций в бетоне за время $\Delta t(d \varepsilon / d t=c o n s t)$, наблюдается нисходяпая часть диаграммы.

Проведенный анализ и полученная диаграмма растяжения бетона с учетом ниспадающей части характеризуют напряженно-деформированное состояние в месте образования нормальной трещины.

\section{5. Напряженно-деформированное состояние растягиваемого армированного} железобетона на участке между трещинами

На других участках растягиваемого элемента бетон работает совместно $\mathrm{c}$ арматурой. Напряженно-деформированное состояние в нормальном сечении растягиваемого железобетонного элемента на участке без трещин, с учетом усадки, неупругих деформаций и ниспадающей части диаграмы $N_{b t}(t)-\varepsilon$ показано на рис.5. 


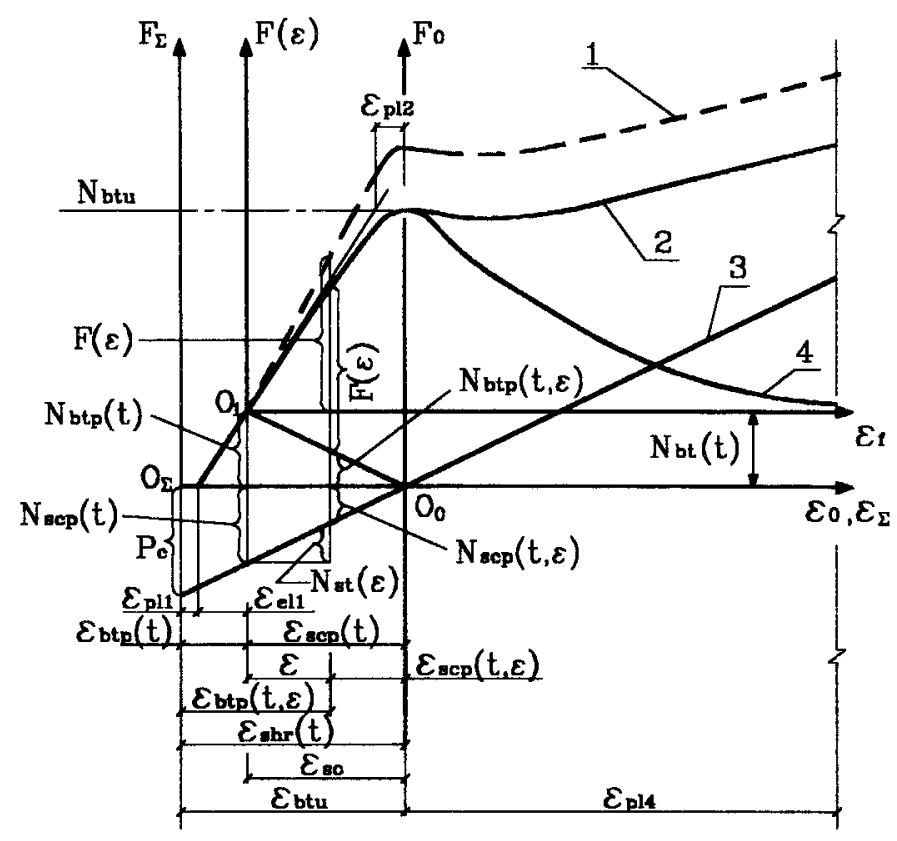

Рис.5. Напряженно-деформированное состояние растягиваемого железобетонного элемента в зоне участка с трещиной с учетом усадки, неупругих деформаций и ниспадающей части диаграммы $N(t)-\varepsilon: 1$ - кривая суммарного усилия в системе координат $F(\varepsilon) O_{1} \varepsilon_{f} ; 2$ та же кривая в системе координат $F_{\Sigma} O_{\Sigma} \varepsilon_{\Sigma}$ с учетом уменышения сжимающего усилия; 3 прямая усилия в арматуре; 4 - ниспадающий участок усилия в бетоне с различным эксцентриситетом приложения силы $F(\varepsilon)$, учитывающий деформации раскрытия нормальных трещин

В этом случае деформации целесообразно измерять на большей базе, охватывающей участок с нормальной трециной. Возможно измерение деформаций и на меньшей базе без нормальных трешин. При этом следует учитывать, что напряженное состояние вдоль длины элемента меняется в зависимости от сцепления арматуры с бетоном и их совместной работы. Так, в зоне, близкой к нормальной трещине, совместная работа бетона с арматурой нарушается, а в месте пересечения сечения трещиной работает только арматура.

Напряженно-деформированное состояние сечений без трещин характеризуется тем, что в сечении работает бетон, а относительные деформации меньше, чем в сечении с трещинообразованием или появившейся трещиной.

Графики кривых усилия - деформации (рис.5) характеризуют средние деформации участка трещинообразования и появившейся трещины. Такая методика оценки напряженно-деформированного состояния принята в Еврокоде [12]. Отметим, что 
ниспадаюшие участки кривых 1 и 2 не пересекают прямую усилия в необетонированной арматуре. Смещение этих кривых характеризует работу растянутого бетона. Ниспадающая часть диаграммы растянутого бетона также не пересекает ось деформаций $O_{\Sigma} \varepsilon_{\Sigma}$. Полученное усилие $F_{u}, R_{u}$ определяется сечением с проявляющимся трещинообразованием, а данный участок снижает деформации по сравнению с сечением, где появится трещина.

Особо следует отметить перераспределение ках локальных, так и общих продольных деформаций вдоль растягиваемого элемента. Одновременно меняется и физический эксцентриситет продольной силы. Эти вопросы требуют отдельного анализа и в данной работе не рассматриваются.

Ниспадаюпцие участки графиков кривых 1, 2 и 4 характеризуют и процесс раскрытия нормальных трещин.

Предложенная методика определения напряженно-деформированного состояния образца при его испытаниях на растяжение с учетом проявления усадки и неупрутих деформаций до загружения позволяет оценить диаграмму растяжения бетона с учетом ниспадающей части и процесса трещинообразования. При этом часть участка нисходящей диаграммы характеризует и процесс образования и раскрытия нормальных трещин при различном эксцентриситете растятивающей силы. Предложенная методика была применена в экспериментальных исследованиях напряженно-деформированното состояния бетонных и железобетонных образцов с учетом их предыстории до загружения.

\section{6. Результаты экспериментальньх исследований}

На растяжение были испытаны три серии бетонных и железобетонных образцов. На рис.6, $a, \sigma$ показаны наиболее характерные результаты напряженнодеформированного состояния образца при растяжении, когда процент армирования $\mu=0.218 \%$ (образцы A1 и А2) и на рис.6, в $\mu=0.54 \%$ (образец А3), а также рис.6, $\Gamma^{-}$ бетонный образец А4. Данные исследований приведены и в работе [13].

Методика обработки результатов исследований изложена в разделах 2..5. При этом учтены процессы усадки, нарастание физико-механических характеристик бетона и неупругие деформации для каждого образца.

Графики кривых усилия-деформации (рис.6, a, б) характеризуют средние деформации участка трещинообразования и появившейся трещины. Такая методика оценки напряженно-деформированного состояния принята в [12]. Отметим, что ниспадающие части кривых 1 и 2 (рис.6, б) не пересекают прямую усилия в необетонированной арматуре. Смещение этих кривых характеризует работу растянутого бетона и раскрывающихся трещин. 
a

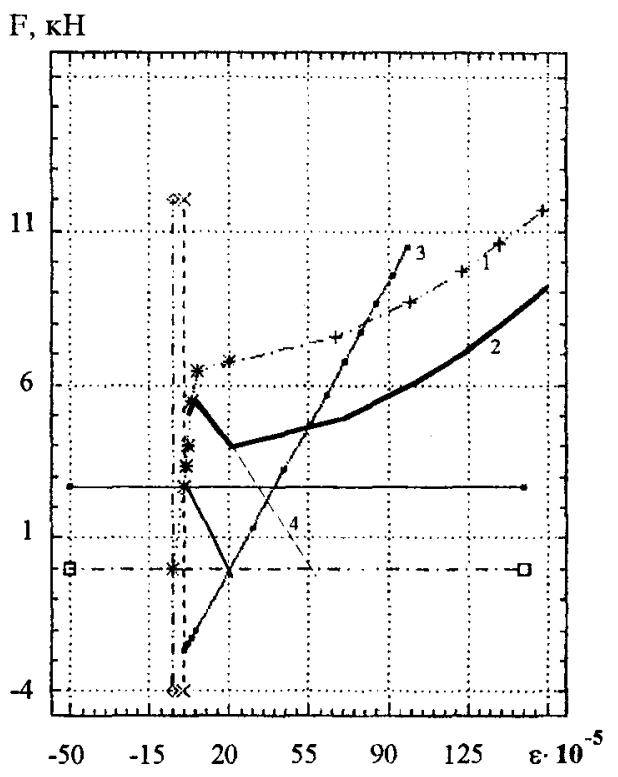

B

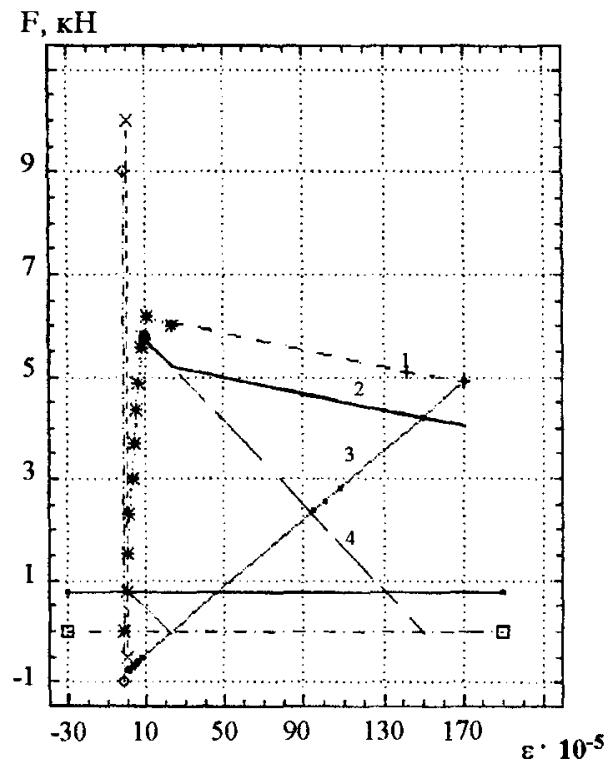

6

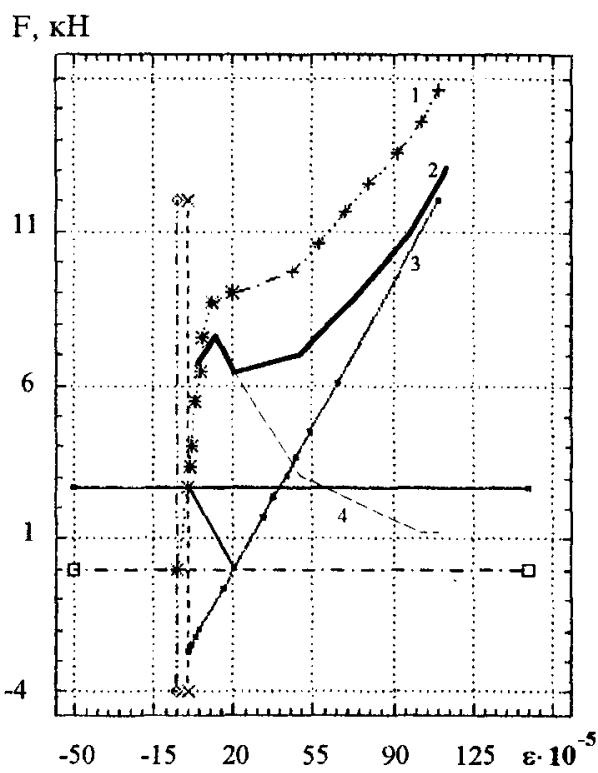

$\Gamma$

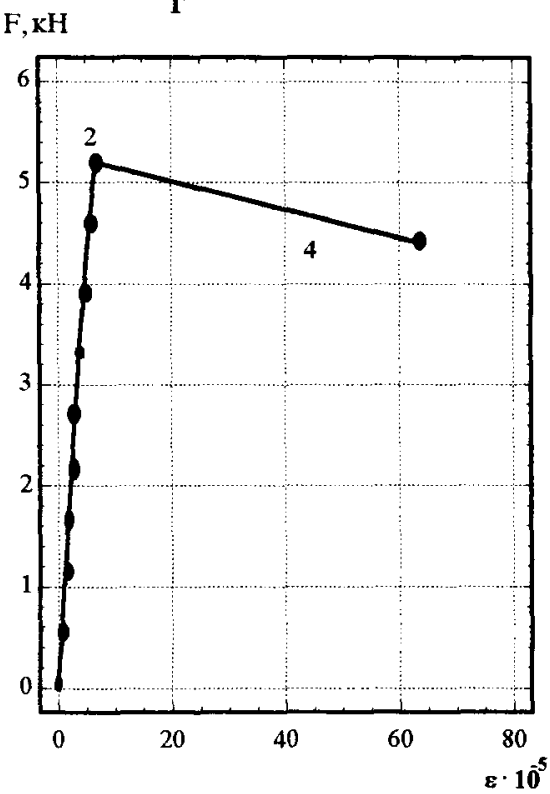

Рис.6. Экспериментальные кривые напряженно-деформированного состояния растягиваемых железобетонных образцов $a-\mathrm{A} 1, \sigma-\mathrm{A} 2$ при проценте армирования $\mu=2,18 \%$ и в - А3 при $\mu=0,54 \%$, а также бетонного образца $\Gamma$ - А4 в месте трещинообразования с учетом усадки, неупругих деформаций и ниспадающей части диаграммы $N_{b t}(t)-\varepsilon: 1$ - кривая суммарного усилия в системе координат $F(\varepsilon) O_{1} \varepsilon_{f} ; 2$ - та же кривая в системе координат $F_{\Sigma} O_{\Sigma} \varepsilon_{\Sigma}$, с учетом сжимающего усилия от усадки; 3 - прямая усилия в арматуре; 4 ниспадаюший участок усилия в бетоне с различным эксцентриситетом приложения силы $F(\varepsilon)$, учитывающий деформации раскрытия нормальной трещины 
Ниспадающая часть диаграммы кривая 4 также не пересекает ось нулевых усилий. Полученное усилие $N_{b t u}$ определяется сечением с проявляющимся трецинообразованием, при этом деформации данного участка меныше по сравнению с деформациями того участка, где появляптся сквозные трещины. Ниспадающие участки графиков кривых 4 на рис. 6 , а и 6 характеризуют и процесс раскрытия нормальных трещин.

На графиках рис.6, $а, \sigma, в$ характерно выделяется точка завершения процесса трещинообразования на кривой 2 (точка $B$ на рис.3). Однако она менее заметна при уменьшении армирования (рис.6, в) и для бетонных образцов (рис.6, I). Аналогичные результаты получены и в других экспериментальных и теоретических исследованиях $[1,14]$

Особо следует отметить перераспределение как локальных, так и общих продольных деформаций вдоль растягиваемого элемента. Одновременно изменяется и физический эксцентриситет продольной силы. Эти вопросы требуют отдельного анализа и в данной работе не рассматриваются.

Предложенная и экспериментально проверенная методика позволяет оценить напряженно-деформированное состояние растянутого железобетона с учетом усадки и неупругих деформаций и выделить нисходяную часть диаграммы растяжения бетона совместно с проявлением и раскрытием нормальной трещины. При этом длина участка нисходящей части диаграммы и ее характер зависят от эксцентриситета приложения растягиваемой силы.

\section{7. Применение результатов исследований в практике проектирования и строительства натурншх конструкций и сооружений}

Методика учета усадки, неупругих деформаций и процессов измерения физикомеханических характеристик бетона была применена в практике проектирования и строительства Каунасских очистных сооружений для канализационных стоков [15, $16,17,18,19,20]$. Так для метантанков емкостью $10000 \mathrm{~m}^{3}$ (рис. 7) были разработаны сприменением результатов настоящих исследований конструкции сборномонолитного железобетонного покрытия. При этом учитывалась различная усадка для сборного и монолитного бетона. Более подробные сведения о конструкции этого покрытия приведены в $[16,19]$. При проектировании конструкции покрытия было необходимо обеспечить требуемую трещиностойкость монолитного бетона. В расчетах усадка моделировалась отрицательными температурными полями, что позволило применять имеюгциеся программы, определяющие напряженнодеформированное состояние методом конечного элемента. Конструкция сборного 
элемента такого покрытия и сечение покрытия с монолитным бетоном показаны на рис. 8 и 9.

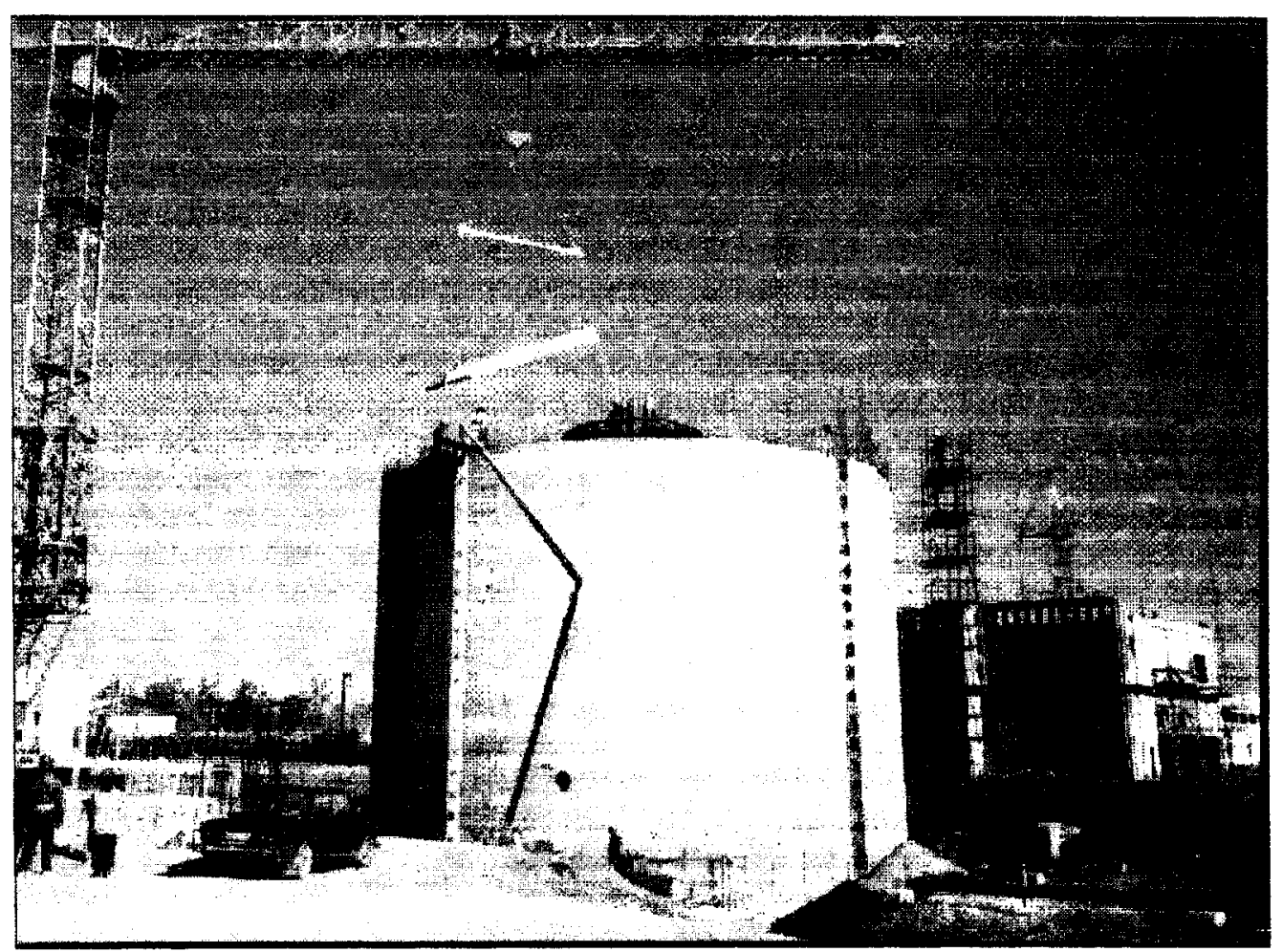

Рис.7 Общий вид монтажа покрьтия метантанка емкостью $10000 \mathrm{~m}^{3}$

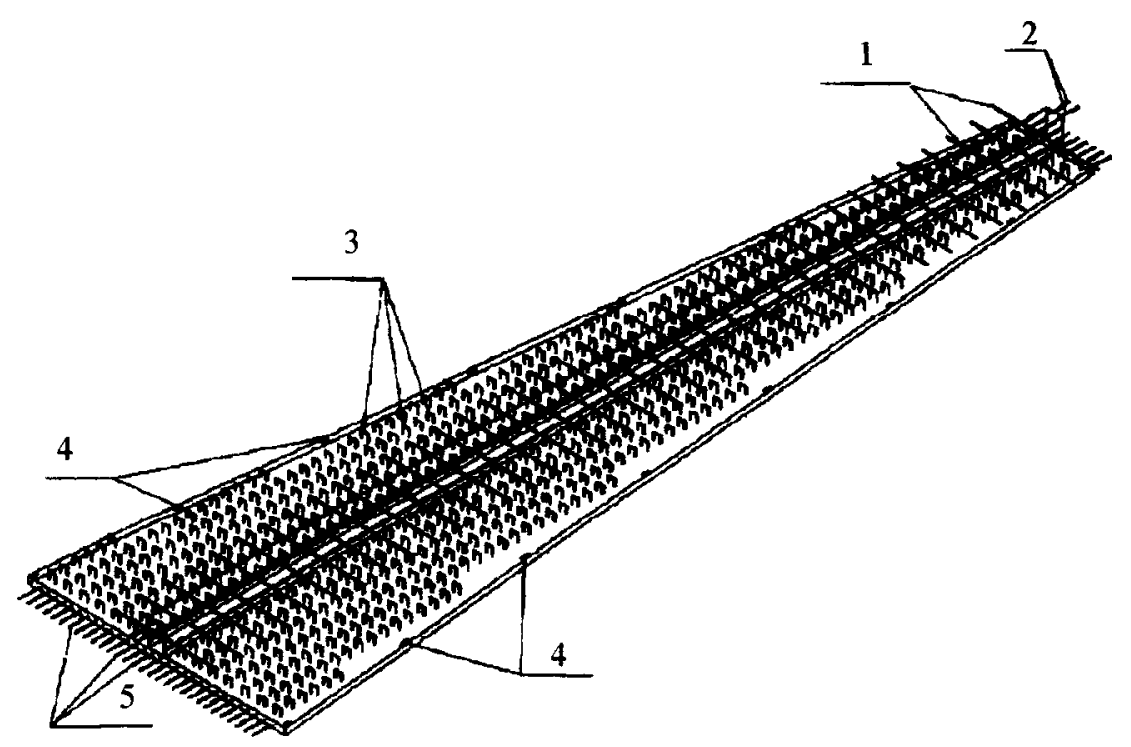

Рис.8. Сборная плита сборно-монолитного покрытия метантанка: 1, 5 - арматура плиты, 2 арматура балки, 3 - вбетонированные петли, 4 - закладные детали 


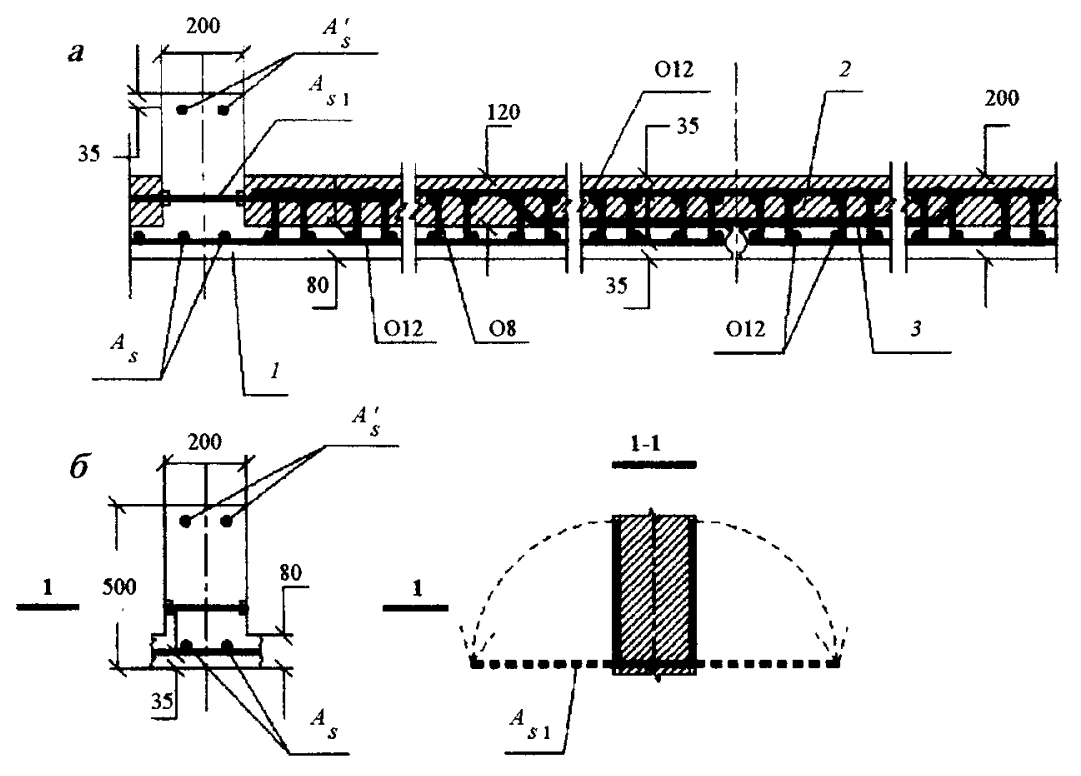

Рис.9. Армирование монолитного бетона и стык сборных плит: а - общий вид; б арматура ребра при бетонировании сборной плиты и после отгиба; 1 - сборная плита, 2 монолитный бетон, 3 - уложенная по сборной плите и анкерованная в монолите арматура, заменяющая стыковку и обеспечивающая работу арматуры в сборном элементе

Следует обратить внимание на оригинальность разработанной конструкіции сборно-монолитного покрытия, позволяющей по продольным граням стыкуемых сборных плит не стыковать радиальную арматуру сборного элемента. Стыкование радиальной арматуры, расположенной в сборном элементе, производится укладкой дополнительной арматуры большей площади по контахтной поверхности сборного и монолитного бетона и анкерованной в монолитном бетоне. Такое решение стыка обеспечило надежную работу покрытия и упростило технологию изготовления как сборных плит, так и сборно-монолитного покрытия.

Сборные элементы покрытия опираются на стены метантанка и центральную монтажную колонну, а сборные плиты одновременно служат опалубкой и несуцим элементом при укладке монолитного бетона (рис.10). В процессе твердения в монолитном бетоне из-за стесненной усадки могут появиться трещины. Поэтому необходимо загружение перекрытия и обжатие монолитного бетона путем опускания опорных частей монтажной колонны. При этом монолитный бетон должен иметь достаточную прочность.

Расчеты позволили определить начало трещинообразования в монолитном бетоне и установить время включения его в работу покрытия, что позволило избежать появления трещин. 


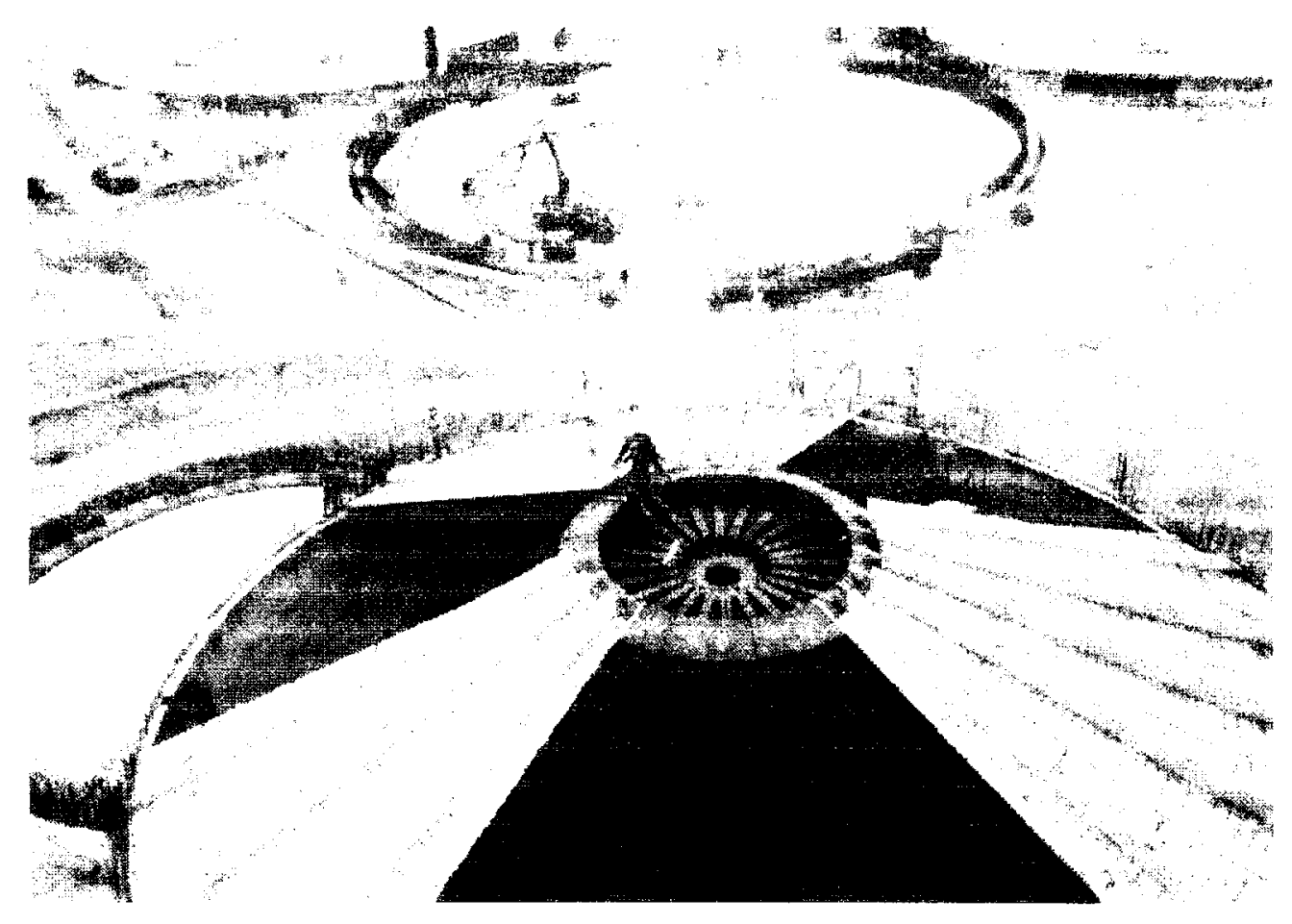

Рис.10 Общий вид покрытия метантанка при монтаже сборных плит

Результаты исследований применялись также в конструктивном обосновании принятой технологии строительных работ при бетонировании радиальных отстойников болыших габаритов (диаметром до 50 м) и участков магистралыных каналов с размерами пропускного отверстия до $3 \times 3$ м $[17,18,20]$. В этих сооружениях учитывалась не только усадка в различное время бетонированных частей хонструкции, но и трение днища по ранее забетонированному основанию. По принятой технологии бетонирования участков магистральных каналов вначале укладывался подготовительный слой, затем бетонировалось днище и лишь после этого монтировалась арматура и бетонировалась верхняя П-образная часть канала (рис.11).

Однако из-за стесненной усадки в разное время бетонированных частей, трения днища канала о бетонную подготовку, сезонного изменения температуры и ее градиента по сечению появлялись нормальные трешины. Было необходимо рассчитать рациональные длины участков бетонирования и подобрать арматуру, обеспечиваюцую требуемую трещиностойкость и ширину раскрытия технологических швов и трещин. Напряженно-деформированное состояние канала при разном времени бетонирования его частей показано на рис.11. Напряжения $\sigma_{4}, \sigma_{3}$ и $\sigma_{1}$ - сжимающие, а $\sigma_{2}$ - растягивающее. Данные по этим исследованиям приведены в работах $[15,17,18]$. 


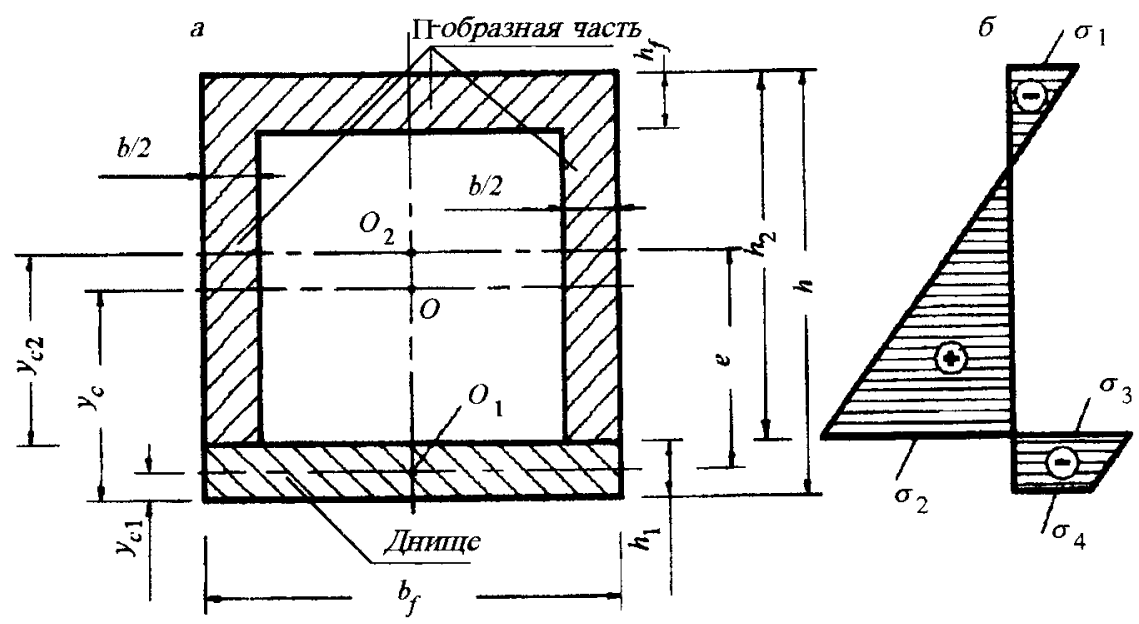

Рис.11. Поперечное сечение канала (а) и эпюра напряжений по нормальному сечению из-за различной усадки бетона II-образной части и днища канала (б): $O$ - центр тяжестей сечения канала; $O_{1}$ - центр тяжести днища; $O_{2}$ - центр тяжести П-образной части канала

Благодаря результатов настояпих исследований, стал возможным учет напряженно-деформированного состояния от воздействия таких факторов, как усадка, неупругие деформации, изменение физико-механических характеристик, изменение и градиент температуры по сечению элемента, а также трение днипа конструкций по уложенному основанию, при гарантии предусмотренной в [7] трешиностойкости, а также ширины раскрытия технологических швов и трещин.

\section{8. Выводы}

1.Проведен анализ определения напряженно-деформированного состояния железобетонного элемента при проявлении усадки и изменении физикомеханических характеристик в процессе твердения бетона.

2.Разработана методика определения экспериментально-теоретическим путем напряженно-деформированного состояния растягиваемого армированного элемента с учетом усадки, неупругих деформаций и изменения физикомеханических характеристик бетона.

3.Экспериментальным путем с применением разработанной методики исследовано напряженно-деформированное состояние бетонных и армированных образцов при растяжении.

4.Оценено напряженное состояние в армированном и неармированном элементе в месте трецинообразования и на участках между трещинами и получена диаграмма растяжения бетона с учетом нисходящей части, при этом учтена предыстория 
загружений, а также влияние таких факторов как усадка, неупругие деформации и изменение физико-механических характеристик бетона в процессе твердения.

5.Методика и результаты исследований применены при оценке напряженнодеформированного состояния в процессе проектирования и строительстве Каунасских очистных сооружений для канализационных стоков.

6.Методика и полученные результаты позволили рассчитать напряженнодеформированное состояние сборно-монолитной железобетонной конструкции покрытия метантанка при различной усадке сборного и монолитного бетона и огределить время включения в работу монолитного бетона, обеспечивающее его трещиностойкость.

7.Результаты исследований были использованы при разработке и конструктивном расчете порядка, технологии и размеров бетонируемых участков крупногабаритных каналов, а также радиальных отстойников диаметром до $50 \mathrm{~m}$, а также позволили обеспечить требуемую трещиностойкость и ширину раскрытия технологических Ішвов и трещин.

8.Практика строительства сооружений из монолитного бетона показала, что разработанная методика и результаты исследований могут быть применены при решения задач напряженно-деформированного состояния крупногабаритных монолитных и сборно-монолитных конструкций и позволят обеспечить качество сооружений при доэксплуатационных воздействиях и обосновать технологию сгроительных работ с учетом всего разнообразия действующих факторов при рациональном армировании.

\section{Литература}

1. Harald Bergner. Minimum Reinforcement of High-Strength Concrete Members Under Centrical Restraint. Darmstadt Concrete,vol.9. Darmstadt, 1994. P.41-48

2. С. В. Александровский Расчет бетонных и железобетонных конструкций на изменение температуры и влажности с учетом ползучести. М.: Стройиздат, 1973. $432 \mathrm{c}$.

3. А. Б. Голышев, В. П. Полишук, Ю. А. Колпаков. Расчет сборно-монолитных конструкций с учетом фактора времени. Киев: Будивельник, 1969. 219 с.

4. Р. Ю. Купляускас, А.-Й. Й. Ноткус. Экспериментальные исследования полной диаграммы растяжения бетона//Железобетонные конструкции, №15. Вильнюс, 1987 , c. $83-89$. 
5. Р. Ю. Купляускас. Распределение деформагий в растянутом бетоне армированной зоны//Материалы 3 международной конференции "Новые строительные материалы, конструкции и технологии". Вильнюс, 1993, с. 200-203.

6. Е.Дулинскас. О методике оценки напряженно-деформированного состояния растянутого железобетона с учетом усадки и неупругих деформаций//4-osios tarptautinès konferencijos "Naujos statybinès medžiagos, konstrukcijos ir technologijos" straipsniai. III tomas. Vilnius: Technika, 1995, p. 61-68.

7. СНиП 2.03.01-84* . Бетонные и железобетонные конструкции. М.: Стройиздат, 1985. $80 \mathrm{c}$

8. В. Н. Байков, Э. Е. Сигалов. Железобетонные конструкции. Общий курс. М.: Стройиздат, 1985, с. 71-73.

9. Н. И. Безухов. Основы теории упругости, пластичности и ползучести. М.: Высшая школа, 1968. $325 \mathrm{c}$.

10.Г. В. Марчюкайтис, Е. Ю. Дулинскас. Напряженно-деформированное состояние преднапряженных железобетонных конструкций при теплообработке. Вильнс. 1975. $122 \mathrm{c}$.

11.Н. Х. Арутюнян. Некоторые вопросы теории ползучести. М.: Гостехиздат, 1952. $300 \mathrm{c}$.

12.CEB-FIP MODEL CODE 1990, Thomas Telfard, 1991. $438 \mathrm{p}$.

13.Е. Дулинскас, Р. Кушляускас. Напряженно-деформированное состояние растянутого железобетонного элемента с учетом усадки и неупругих деформаций бетона элементов//4-osios tarptautines konferencijos "Naujos statybinès medžiagos, konstrukcijos ir technologijos" straipsniai. III tomas. Vilnius: Technika, 1995, p. 102-107.

14.А. Кудзис, Р. Кушляскас. Критерии расчета сопротивления трещинообразования растягиваемых железобетонных элементов//4-osios tarptautinès konferencijos "Naujos statybinès medžiagos, konstrukcijos ir technologijos" straipsniai. III tomas. Vilnius: Technika, 1995, p. 31-36.

15. E.Dulinskas, A.Jurkša. Didelių matmenụ dèžinio skerspjūvio monolitinio gelžbetonio kanalų deformacinių ruožų racionalių ilgių ir armavimo nustatymas/4-oji tarptautinè konferencija "Naujos statybinès medžiagos, konstrukcijos ir technologijos." II tomas. Vilnius: Technika, 1995 , p. $218-223$

16. E.Dulinskas, A.Jurkša. Metantanko surenkamo-monolitinio gelžbetonio stogo konstrukcija//4 oji tarptautiné konferencija "Naujos statybines medžiagos, konstrukcijos ir technologijos." III tomas. Vilnius: Technika, 1995, p. 20 - 25.

17. UAB Mokslinių inžinerinių paslaugų centras "Inžinerija". Kauno vandenvalos ịrenginiụ betonuojamų kanalų ruožų ilgiu bei skerspjūvio dalių betonavimo eiliškumo parinkimas, 
iqvertinant betono susitraukimą bei temperatūrines deformacijas. Ūkiskaitinès sutarties Nr.407 ataskaita. Vilnius, $1994.45 \mathrm{p}$.

18. UAB Moksliniụ inžineriniu paslaugu centras "Inžinerija". Kauno vandenvalos įrenginių kanalụ deformacinių ruožų ilgių bei armavimo skaičiavimas, ịvertinant fiksuotą trintį tarp kanalo pado ir pagrindo bei suminius didelius temperatūrinius išilginius poslinkius ir skerspjūvio temperatūrinius gradientus. Ūkiskaitinès sutarties Nr.416 ataskaita. Vilnius, 1995. $97 \mathrm{p}$.

19. UAB Mokslinių inžinerinių paslaugų centras "Inžinerija". Kauno vandenvalos įrenginių metantanko konstrukcijy patikslinimas, ịvertinant VSL INTERNATIONAL sistemos ịtemptosios armatūros taikymą, surenkamų-monolitinių stogo konstrukciju su centrine montažine kolona sukūrimą ir principinių pasiūlymų statybos darbų technologijai bei ịrangai pateikimas. Ūkiskaitinés sutarties Nr. 414 ataskaita. Vilnius, 1994. $71 \mathrm{p}$.

20. UAB Mokslinių inžinerinių paslaugu centras "Inžinerija". Kauno valymo ịrenginių radialinio sésdintuvo betonuojamų ruožų matmenu bei betonavimo technologijos konstrukcinis patikrinimas, įvertinant betono suvaržyto susitraukimo ir temperatūrinius poveikius. Ũkiskaitinès sutarties Nr.409 ataskaita. Vilnius, $1994.56 \mathrm{p}$.

\section{TEMPIAMO GELŽBETONIO IৃTEMPIMU -DEFORMACIJU BÜVIO, IVERTINANT SUSITRAUKIMA IR NETAMPRIAS DEFORMACLJAS, SKAIČIAVIMO IR EKSPERIMENTINIO TYRIMO METODIKA}

\section{E.Dulinskas}

S a n tra a k

Straipsnyje analizuojamas armuoto gelžbetonio pradinis įtempimų-deformacijų būvis betono kietejimo metu, ivertinant betono fizinių-mechaninių rodiklių padidejimą, susitraukimą ir netamprias deformacijas. Sukurta skaičiavimo metodika, kuri juvertina pradinị būvị, nustatant trumpalaike apkrova tempiamo elemento betono ir armatūros j̇tempimus bei deformacijas. Taikant šią metodiką eksperimentiniu-teoriniu būdu nustatomas j̇tempimų-deformacijy būvis ir išskiriama tempiamo betono ittempimu-deformaciju $\sigma-\varepsilon$ pilna diagrama, ̨̣skaitant ir jos žemyn krentančią dali. Panaudojant eksperimentinių tyrimų rezultatus, nustatytos tempiamo nearmuoto ir armuoto betono pilnos diagramos, gautas pakankamas teoriniy ir eksperimentiniu rezultaty patikimumas. Sukurta metodika ir tyrimo rezultatai pritaikyti projektuojant ir statant monolitinio ir surenkamojo-monolitinio gelžbetonio valymo įrenginių statinių konstrukcijas. Taikant šią metodiką, buvo nustatytas konstrukcijų ịtempimų-deformacijų būvis ikieksploatacineje bei eksploatacinèje stadijose ir rekomenduota statybos darbų technologija, užtikrinanti reikiamą konstrukcijų kokybę, esant jivairiems poveikiams. 


\section{ESTIMATION METHOD AND EXPERIMENTAL INVESTIGATION OF STRESS-STRAIN STATE FOR TENSILE RC INCLUDING ASSFSSMENT OF SHRINKAGE AND NON-LINEAR STRAINS}

\section{E.Dulinskas}

S u m m a r y

In this paper, a stress-strain state is analysed for hardening reinforced concrete due shrinkage, increase of physical parameters and non-linear strains of concrete. A method has been developed for assessment of initial stress-strain for reinforced concrete specimens subjected to short-term loading. Stresses and strains in reinforcement and concrete are estimated by experimental-theoretical method and $\sigma-\varepsilon$ diagram for tensile concrete including the descending branch is defined.

Experimental investigations of tensile reinforced and non-reinforced members have been carried out for defining the descending part of $\sigma-\varepsilon$ diagram. Sufficient agreement of experimental and predicted data have been achieved.

The method and results of these investigations have been applied for design and building of water cleaning equipment made from cast-in-situ and pre-cast concrete. Stress-strain state of structures has been determined for different stages of construction and each of them the required technology has been chosen.

Careful examination of structures of the buildings built allows to conclude that the above method can used for calculation and design of cast-in-situ and pre-cast reinforced concrete structures. 